\title{
A CASE ILLUSTRATING THE EFFECT OF CALCIUM DISODIUM VERSENATE (CaNa 2 E.D.T.A.) ON CHRONIC MERCURY POISONING
}

\author{
BY \\ S. M. WOODCOCK \\ From Barnet General Hospital \\ (RECEIVED FOR PUBLICATION NOVEMBER 11, 1957)
}

Chronic mercury poisoning treated with calcium disodium versenate ( $\mathrm{CaNa}_{2}$ E.D.T.A.) has not previously been reported in England.

In this case treatment with $2: 3$ dimercaptopropanol (B.A.L.) and $\mathrm{CaNa}_{2}$ E.D.T.A. was used and the effect of these on urinary mercury excretion was compared.

\section{Case Report}

The patient was a girl of 24 who had worked for six months in a factory " throwing" coils. This process consisted of calibrating coils containing mercury for use as pressure gauges. On an average, two or three coils a day burst during testing, so that the work bench was usually contaminated with metallic mercury. Despite warnings about the danger of ingesting mercury, she ate sweets at work and had a habit of sucking her fingers. She had felt unwell for about a month before admission, with general lassitude, anorexia, and loss of weight. She had noticed a metallic taste in her mouth but denied excess salivation and her teeth and gums were healthy. She was admitted to hospital on July 6,1957 , oedema of the ankles, hands, and eyelids having been noted on the previous day. There was no other abnormality on physical examination. Blood pressure was $125 / 80 \mathrm{~mm}$. $\mathrm{Hg}$.

Investigations on admission showed marked albuminuria, $900 \mathrm{mg}$. per $100 \mathrm{ml}$. There were no pus cells or casts in the urine and only occasional red cells. Haemoglobin was $98 \%$ and the blood urea level $40 \mathrm{mg}$. \%, serum proteins $5 \mathrm{~g}$. (albumin $3.2 \mathrm{~g}$., globulin $1.8 \mathrm{~g}$.). The urinary mercury excretion in 24 hours was $460 \mu \mathrm{g}$. The normal excretion of urinary mercury is less than $100 \mu \mathrm{g}$. in 24 hours (Bidstrup, Bonnell, Harvey, and Locket, 1951).

With bed rest and a low-protein diet, the oedema cleared, urinary output improved, and the metallic taste disappeared, but albuminuria persisted and the urinary mercury excretion was higher at $475 \mu \mathrm{g}$. on July 24 . A course of B.A.L. was given, consisting of $2 \mathrm{ml}$. injections of $5 \%$ solution, three times on the first day, twice on the second, and then daily for two days. This did not increase the urinary mercury excretion (Fig. 1) and was followed by nausea and an increase in albuminuria.
A five-day course of intravenous $\mathrm{CaNa}_{2}$ E.D.T.A.. $3 \mathrm{~g}$. daily, was started on August 4 and was followed by a rise in urinary mercury excretion to $700 \mu \mathrm{g}$. in 24 hours on August 9. A course of oral $\mathrm{CaNa}_{2}$ E.D.T.A., 3 g. daily for seven days, starting on August 14, did not increase urinary mercury excretion: unfortunately the faecal mercury excretion was not measured.

By August 21, the oedema had cleared and albuminuria decreased. A further course of $\mathrm{CaNa}_{2}$ E.D.T.A. intravenously in the same dosage as before again increased the urinary mercury excretion. The patient was discharged well, free from albuminuria, some three months after admission. Fig. 1 shows the treatment given and urinary mercury and protein excretion.

\section{Method of Estimating Mercury in Urine}

The method used to estimate mercury was that of Rolfe, Russell, and Wilkinson (1955) as given by King and Wootton (1956).

In order to assess the accuracy of the recovery of mercury in the presence of the complexing agents, blank and check estimations were carried out as in the Table.

\section{TABLE}

BLANK AND CHECK ESTIMATIONS OF MERCURY IN URINE

\begin{tabular}{|c|c|}
\hline Specimen & $\begin{array}{c}\text { Amount of Mercury } \\
\text { Detected }(\mu \mathrm{g} .)\end{array}$ \\
\hline 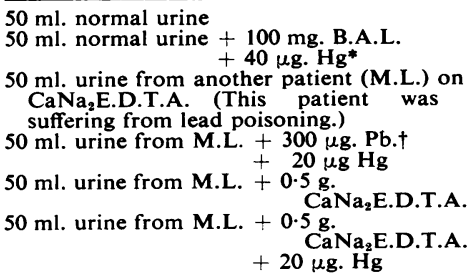 & $\begin{array}{r}0 \\
21 \\
1 \\
21\end{array}$ \\
\hline
\end{tabular}

* Added as mercuric chloride, as in the standard solution in the method of Rolfe et al. (1955).

tAdded as lead nitrate in solution.

These estimations render it unlikely that a low "B.A.L.: $\mathrm{Hg}$ " value might have been due to inadequate break-up 
of the B.A.L.: $\mathrm{Hg}$ complex during ashing. The likelihood that a high " $\mathrm{CaNa}_{2}$ E.D.T.A.: $\mathrm{Hg}$ " value might have been due to inclusion in the analysis results of other metals liberated by $\mathrm{CaNa}_{2}$ E.D.T.A. is also excluded by these estimations.

\section{Comment}

This case is reported as it is contrary to the experience of Bell, Gilliland, and Dunn (1955) who found that B.A.L. did increase urinary excretion of mercury in a case of chronic poisoning and that $\mathrm{CaNa}_{2}$ E.D.T.A. did not. Bell et al. administered $\mathrm{CaNa}_{2}$ E.D.T.A. intravenously as a $3 \%$ solution, giving $2.5 \mathrm{~g}$. daily for five days. They do not state the dose of B.A.L. given. In the present case intravenous $\mathrm{CaNa}_{2}$ E.D.T.A. on two occasions increased mercury excretion while B.A.L. did not. Treatment with B.A.L. was in fact followed by increased albuminuria and some nausea, possibly resulting from a toxic effect of B.A.L. itself (Hunter, 1957).

It is concluded that intravenous $\mathrm{CaNa}_{2}$ E.D.T.A. is of value in the treatment of chronic mercury poisoning.

\section{Summary}

A case of chronic mercury poisoning treated with $2: 3$ dimercaptopropanol (B.A.L.) and intravenous calcium disodium versenate $\left(\mathrm{CaNa}_{2}\right.$ E.D.T.A.) is reported.

Contrary to previous reports, $\mathrm{CaNa}_{2}$ E.D.T.A. resulted in increased urinary excretion of mercury, while B.A.L. did not.

It is concluded that $\mathrm{CaNa}_{2}$ E.D.T.A. is of value in the treatment of chronic mercury poisoning.

I thank Dr. G. Riddell Royston for permission to publish this case. I acknowledge gratefully the help given by Mr. Winks of Barnet General Hospital, who did all the mercury estimations.

\section{REFERENCES}

Bell, R. F., Gilliland, J. C., and Dunn, W. S. (1955). Arch. industr. Hith, 11, 231.

Bidstrup, P. L., Bonnell, J. A., Harvey, D. G., and Locket, S. (1951) Lancet 2856

Hunter, D. (1957). Diseases of Occupations, 2nd ed., p. 285. The

King, English Universities Press, London. Biochemistry, 3rd ed., p. 177. Churchill, London.

Rolfe, A. C. Russell, F. R., and Wilkinson, N.'T. (1955). Analyst 80, 523 . 